\title{
Hematopoietically-Expressed Homeobox Protein HHEX
}

National Cancer Institute

\section{Source}

National Cancer Institute. Hematopoietically-Expressed Homeobox Protein HHEX. NCI

Thesaurus. Code C114959.

Hematopoietically-expressed homeobox protein HHEX (270 aa, 30 kDa) is encoded by the human HHEX gene. This protein is involved in the negative regulation of transcription. 